\author{
ACTA MYCOLOGICA \\ Vol. 47 (2): 169-173 \\ 2012
}

\title{
Mycorrhization level in truffle plants and presence of concurrent fungi
}

\author{
LEONARDO BACIARELLI FALINI, GIAN MARIA NICCOLÒ BENUCCI, \\ MATTIA BENCIVENGA and DOMIZIA DONNINI \\ Department of Applied Biology, University of Perugia, Borgo XX Giugno \\ I-74-06121 Perugia, domizia@unipg.it
}

Baciarelli Falini L., Benucci G.M.N., Bencivenga M., Donnini D.: Mycorrhization level in truffle plants and presence of concurrent fungi. Acta Mycol. 47 (2): 169-173, 2012.

In Italy, to improve good practices for truffle cultivation, some regional governments require specific certification of mycorrhization level and plant quality for marketing, outplanting and establishment of truffle orchards. The Department of Applied Biology at the University of Perugia has dealt with certification of truffle plants since the 1980's. Here we show the mycorrhization analysis of different host species previously inoculated with truffle spores by an Italian commercial nursery.

Key words: ectomycorrhizas, mycorrhized seedlings, Tuber, truffle cultivation, commercial nurseries

\section{INTRODUCTION}

It is known nowadays that the quality of truffle plants produced by commercial nurseries, as well as the selection of the plantation site according to soil and climate conditions, are essential prerequisites for good truffle cultivation. The concept of quality is essentially based on: i) high percentage of truffle ectomycorrhizas (ECM); ii) absence or low percentage of concurrent fungi; iii) homogeneous and healthy plant development. Some ECM of concurrent fungi that grow in greenhouses were already described (Meotto, Carraturo 1987-88; Bencivenga et al. 1995a; Donnini, Bencivenga 1995; Amicucci et al. 2001; Baciarelli Falini et al. 2006; Benucci et al. 2012), and although their role in truffle cultivation is not known, their presence in the root system of truffle seedlings is negative because they reduce truffle mycorrhization by occupying non colonized root tips. 
Several research centres and universities have developed methodologies of analysis and certification of truffle plants based on both morphological and molecular tools (Govi et al. 1995; Fischer, Colinas 1996; Reyna et al. 2002).

In Italy, to improve good practices for truffle cultivation, some regional governments require specific certification of mycorrhization level and plant quality for marketing, out-planting and establishment of truffle orchards.

\section{MATERIAL AND METHODS}

We analyzed the mycorrhization level of seedlings belonging to Quercus pubescens Willd., Ostrya carpinifolia Scop. and Corylus avellana L. infected with Tuber aestivum Vittad. Seedlings were cultivated in the same nursery and located in the same greenhouse with the same environmental conditions. In every season, for 5 years (2007-2011), seedlings were sampled from homogeneous plant batches, and a morphological and molecular analysis was carried out to quantify the presence of truffle ectomycorrhizae (ECM) and any other concurrent ECM fungi.

The mycorrhization level was evaluated following the official method for Italian truffle plants certifications (Bencivenga et al. 1995b) which was modified after many years of operator experience (Donnini 2005). The method comprised 3 phases: i) visual morphological assessment of the entire root system; ii) identification and percentage evaluation of Tuber and non-Tuber ECM; iii) molecular analysis of all morphotypes. A truffle plant can be certified and considered suitable for market and truffle cultivation when: 1 ) the percentage of Tuber $\geq 30 \%$; ii) the percentage of other ECM fungi is $<15 \%$; iii) the percentage of Tuber minus the percentage of other ECM fungi is $\geq 20$. We analyzed 1-3\% of seedlings for each batch produced. A homogeneous group of seedlings (i.e., a batch) is suitable for truffle cultivation when $\geq 80 \%$ of analyzed seedlings are certified.

In the whole dataset of 1426 plants in total, for each year (from 2007 to 2011) and species (i.e., oak, hazel, hornbeam), 20 samples (i.e., truffle-seedlings) were randomly chosen using R statistical program (R Development Core Team 2011) for a total of 300 samples, 100 each host species. The Shapiro-Wilk test was used to attest normality of the data. The Tukey test was used in conjunction with ANOVA to find which means were significantly different from one another.

\section{RESULTS}

The mycorrhization of oak seedlings (Tab. 1$)$ resulted the lowest $(\approx 43 \%)$ compared to hornbeam and hazel ( $\approx 52 \%$, each). With regard to yearly fluctuations in mycorrhization (Tab. 2) we showed that mycorrhization percentages differed depending on the host and year selected. For example in year 2009 mycorrhization levels were significant for oak $(\approx 57 \%)$ and hazel $(\approx 62 \%)$, but not at all for hornbeam 
$(\approx 30 \%)$. The year 2010 was very good for hornbeam $(\approx 67 \%)$ and hazel $(\approx 58 \%)$, but bad for oak $(\approx 38 \%)$. Hornbeam was also the host which showed higher standard errors than hazel and oak, confirming the high variability of mycorrhization revealed during the analysis. Oak seedlings showed to be more homogeneous and values of mycorrhization are nearer to the mean value.

\section{Table 1}

Levels of mycorrhization with Tuber aestivum between different host species. Values (means $\pm \mathrm{SE}, \mathrm{n}=100$ ) with different letters are significantly different at $\mathrm{P}=0.05$ and $\mathrm{df}=2,299$

\begin{tabular}{|l|c|c|c|}
\hline \multicolumn{1}{|c|}{ Host } & Mean & \multicolumn{2}{c|}{ Groups } \\
\hline Hazel & $52.35 \pm 1.87$ & $\mathrm{a}$ & \\
\hline Hornbeam & $51.65 \pm 2.50$ & $\mathrm{a}$ & $\mathrm{b}$ \\
\hline Oak & $42.90 \pm 1.58$ & & \\
\hline
\end{tabular}

Table 2

Levels of mycorrhization with Tuber aestivum among different host species and years. Values (means $\pm \mathrm{SE}, \mathrm{n}=20$ ) with different letters are significantly different at $\mathrm{P}=0.05$ and $\mathrm{df}=4,99$

\begin{tabular}{|c|c|c|c|}
\hline Year & Oak & Hazel & Hornbeam \\
\hline 2007 & $42.50 \pm 3.15 \mathrm{~b}$ & $48.00 \pm 3.91 \mathrm{ab}$ & $62.00 \pm 4.05 \mathrm{a}$ \\
\hline 2008 & $39.50 \pm 3.80 \mathrm{~b}$ & $47.25 \pm 4.28 \mathrm{ab}$ & $58.25 \pm 3.98 \mathrm{ab}$ \\
\hline 2009 & $56.75 \pm 2.33 \mathrm{a}$ & $62.25 \pm 3.51 \mathrm{a}$ & $30.25 \pm 6.10 \mathrm{c}$ \\
\hline 2010 & $38.50 \pm 4.22 \mathrm{~b}$ & $58.25 \pm 3.94 \mathrm{ab}$ & $66.75 \pm 4.48 \mathrm{a}$ \\
\hline 2011 & $37.25 \pm 1.94 \mathrm{~b}$ & $46.00 \pm 4.21 \mathrm{~b}$ & $41.00 \pm 4.90 \mathrm{bc}$ \\
\hline
\end{tabular}

Table 3 shows the presence of concurrent fungi. Oaks resulted less contaminated than hazels and hornbeams. The mean frequency of mycorrhization was the lowest in oak $(0.17 \pm 0.10)$ and the highest in hornbeam $(0.38 \pm 0.37)$. It is interesting to note that in the year 2009 all 20 hornbeams analyzed showed the presence of concurrent fungi.

\section{Table 3}

Frequency per year $(n=20)$, mean frequency $(n=100)$ and standard deviation of co-occurrent fungi among host species

\begin{tabular}{|c|c|c|c|c|c|c|c|}
\hline \multirow{2}{*}{ Host } & \multicolumn{5}{|c|}{ Frequency } & $\begin{array}{c}\text { Mean } \\
\text { Frequency }\end{array}$ & $\begin{array}{c}\text { Standard } \\
\text { Deviation }\end{array}$ \\
\cline { 2 - 7 } & 2007 & 2008 & 2009 & 2010 & 2011 & 0.17 & 0.10 \\
\hline Oak & 0.30 & 0.20 & 0.05 & 0.10 & 0.20 & 0.28 & 0.16 \\
\hline Hazel & 0.20 & 0.10 & 0.20 & 0.40 & 0.50 & 0.38 & 0.37 \\
\hline
\end{tabular}




\section{DISCUSSION}

In relation to results obtained in this study is apparently more appropriate to select hazel and hornbeam seedlings that showed high rate of mycorrhization with Tuber aestivum as opposed to oak, but on the other hand these are also more colonized by co-occurrent fungi. This tends to be the cases in the field too, because usually hazel and hornbeam trees grow faster and often present more ectomycorrhizal contaminants that other species, consequently the mycorrhization with Tuber is lower than in oaks (Donnini et al. 2003; De Miguel, Sáez 2005; Benucci et al. 2011).

We can hypothesize that on the contrary the best host species is oak, which grows and establishes mycorrhizal symbiosis slower than other species, and seems likely to prefer Tuber to other mycorrhizal fungi in the nursery setting.

This was only a partial study of the large amount of data collected during many years checking and certifying mycorrhized seedlings in several of the most important Italian nurseries.

A complete data elaboration would extend the knowledge on the quality of truffle plants produced by nurseries and could improve mycorrhization methodologies, the inoculation techniques adopted by nurseries and the subsequent success of truffle cultivation. In order to have a European market of truffle plants, it is fundamental to develop a standard method of certification recognised by all countries.

Acknowledgment. We are grateful to the commercial nurseries which took part in this study for their technical support and contribution to improving the realization of a method for quality control of truffle seedlings.

\section{REFERENCES}

Amicucci A., Zambonelli A., Guidi C., Stocchi V. 2001. Morphological and molecular characterization of Pulvinula constellatio ectomycorrhizae. FEMS Microbiol. Lett. 194: 121-125.

Baciarelli Falini L., Rubini A., Riccioni C., Paolocci F. 2006. Morphological and molecular analyses of ectomycorrhizal diversity in a man-made T. melanosporum plantation: description of novel trufflelike morphotypes. Mycorrhiza 16: 475-484.

Bencivenga M., Di Massimo G., Donnini D., Tanfulli M. 1995a. Micorrize inquinanti frequenti nelle piante tartufigene. Nota 1 inquinanti in vivaio. Micol. Ital. 2: 167-178.

Bencivenga M., Donnini D., Tanfulli M., Guiducci M. 1995b. Tecnica di campionamento delle radici e degli apici radicali per la valutazione delle piante micorrizate. Micol. Ital. 2: 35-47.

Benucci G. M. N., Gogan Csorbai A., Baciarelli Falini L., Bencivenga M., Di Massimo G., Donnini D. 2012. Mycorrhization of Quercus robur L., Quercus cerris L. and Corylus avellana L. seedlings with Tuber macrosporum Vittad. Mycorrhiza 22: 639-646.

Benucci G. M. N., Raggi L., Albertini E., Grebenc T., Bencivenga M., Falcinelli M., Di Massimo G. 2011. Ectomycorrhizal communities in a productive Tuber aestivum Vittad. orchard: composition, host influence and species replacement. FEMS Microbiol. Ecol. 76: 170-184.

De Miguel A. M., Sáez R. 2005. Algunas micorrizas competidoras de plantaciones truferas. Biol. Universidad de Navarra, Serie Botánica 1-18.

Donnini D. 2005. Controllo morfologico e certificazione delle piante micorrizate. (In:) D. Donnini, M. Bencivenga, A. Gobbini (eds). Seminario sullo stato attuale della tartuficoltura italiana, SpoletoNorcia: 22-27.

Donnini D., Bencivenga M. 1995. Micorrize inquinanti frequenti nelle piante tartufigene. Nota 2 inquinanti in campo. Micol. Ital. 2: 185-207. 
Donnini D., Baciarelli Falini L., Bencivenga M. 2003. Indagine preliminare sulla affinità di Quercus pubescens e Ostrya carpinifolia nei confronti di Tuber melanosporum, Tuber aestivum e Tuber brumale. Micol. Ital. 29-35.

Fischer C., Colinas C. 1996. Methodology for certification of Quercus ilex seedlings inoculated with Tuber melanosporum for commercial application. First International Conference on Mycorrhiza, Berkeley, California.

Govi G., Bencivenga M., Pacioni G., Palenzona M., Tocci A., Zambonelli A. 1995. Presentazione del metodo di valutazione delle piante micorrizate con funghi del gen. Tuber basato sulla caratterizzazione morfologica delle micorrize. Regioni: Piemonte, Lombardia, Veneto, Emilia Romagna, Marche, Toscana, Umbria, Lazio, Molise, Abruzzo.

Meotto F., Carraturo P. 1987-88. Ectomicorriza di Sphaerosporella brunnea (A.\&S.) Svrcek \& Kubicka in piantine tartufigene. Allionia 28: 109-116.

R Development Core Team 2011. R: A language and environment for statistical computing. R Foundation for Statistical Computing, Vienna, Austria.

Reyna S., Boronat J., Palomar E. 2002. Quality control of plants mycorrhized with Tuber melanosporum Vitt. Edible mycorrhizal mushrooms and their cultivation. Proceedings of the Second International Conference on Edible Mycorrhizal Mushrooms, Crop \& Food Research, Christchurch, New Zealand: $1-9$. 